\title{
Histopathological study of canine sebaceous tumors and their association with PCNA expression by immunohistochemistry*
}

\section{Estudo histopatológico de tumores sebáceos caninos e sua associação com a expressão de PCNA por imuno-histoquímica}

\author{
Fabíola Barroso Costa ${ }^{* *}$ Kássia Valéria Gomes Coelho da Silva, ${ }^{* *}$ Juliana da Silva Leite, ${ }^{* *}$ Franciele Basso Fernandes Silva, ${ }^{* *}$ \\ Bárbara Paula dos Santos Batista, ${ }^{* *}$ Juliana Freitas de Mello e Silva, ${ }^{* *}$ Ana Maria Reis Ferreira**
}

\begin{abstract}
Resumo
Tumores sebáceos são comuns em cães. Tais tumores incluem lesões benignas e malignas. A avaliação imunohistoquímica desses tumores pode agregar informações sobre a origem e o grau de malignidade das lesões. Para este fim, sessenta e uma amostras, incluindo pele normal e tumores sebáceos foram selecionadas de cães de várias raças e idades, sem predileção por sexo, do arquivo do Serviço de Patologia Veterinária da Universidade Federal Fluminense, Niterói/RJ, Brasil. As amostras passaram por processamento histológico, coloração de rotina e imuno-histoquímica com anti-PCNA (proliferating cell nuclear antigen). Foram realizadas análises estatísticas descritivas além dos testes de Wilcoxon-Mann-Whitney para comparar a distribuição da marcação de anti-PCNA entre grupos de variáveis. Para variáveis com mais de dois grupos, aplicou-se a Análise de Variância (ANOVA). A idade média dos animais afetados foi de 10.56 anos. As raças mais afetadas foram Caniches e Cocker Spaniel, e ainda animais sem raça definida. Houve imunomarcação de PCNA em tumores benignos, malignos, e ainda em lesões hiperplásicas com intensidade variada. A maioria dos tumores eram neoplásicos representando $67.92 \%$ do total; destes, $75.00 \%$ eram benignos. 0 adenoma sebáceo foi a neoplasia mais frequente (37.74\%). Não foram encontradas diferenças significativas nas distribuições de anti-PCNA entre os grupos das variáveis sexo, idade, status reprodutivo, localização e tamanho do tumor e diagnóstico histopatológico. Embora não haja estudos com anti-PCNA em tumores sebáceos caninos, numerosas publicações apontam seu valor preditivo em outras neoplasias. Com isso, a finalidade deste estudo foi avaliar a expressão de anti-PCNA em tumores sebáceos caninos e sua possível associação com a malignidade das lesões.
\end{abstract}

Palavras-chave: adenoma, cães; imuno-histoquímica, neoplasias da glândula sebácea.

\begin{abstract}
Sebaceous tumors are common in dogs. These tumors include both benign and malignant lesions. Immunohistochemical evaluation of these tumors can aggregate information regarding the origin and degree of malignancy of the lesions. Focusing on this matter, sixty-one samples including normal skin and sebaceous tumors were selected from dogs of various breeds and ages, with no predilection for sex, from the archive of Veterinary Pathology Service of Federal Fluminense University, Niterói/RJ, Brazil. The samples underwent to histological processing, routine staining and immunohistochemistry with anti-PCNA (proliferating cell nuclear antigen). Descriptive statistical analysis was performed, the Wilcoxon-Mann-Whitney test was used to compare the distribution of anti-PCNA labelling in different groups of variables. In case there were more than two groups, the Analysis of Variance (ANOVA) test was performed. The mean age of the affected animals was 10.56 years. The most affected breeds were Caniches and Cocker Spaniels, as well as mixed breed animals. There was immunostaining of PCNA in both benign and malignant tumors, as well as in hyperplasic lesions with varying intensity. Most of the tumors were neoplasms which represented $67.27 \%$ of the total sample; within these, $75.00 \%$ were benign. The most frequent neoplasm was sebaceous adenoma (37.74\%). Results indicated no statistical difference in the distribution of anti-PCNA labelling between the groups of sex, age, reproductive status, localization, size of tumor, and histopathological diagnosis. Although there are not many studies analyzing anti-PCNA labelling in sebaceous tumors, several of them pointed out to the predictive value in other neoplasms. With this matter in mind, we intended to evaluate the expression of anti-PCNA in canine sebaceous tumor and a possible association with the malignancy of the lesions.
\end{abstract}

Keywords: adenoma, dogs, imunohistochemistry, sebaceous gland neoplasms.

\footnotetext{
${ }^{*}$ Recebido em 14 de abril de 2020 e aceito em 12 de setembro de 2020.

**Federal Fluminense University; Faculty of Veterinary; Department of Pathology and Veterinary Clinic; Niterói, Rio de Janeiro; Brazil.

${ }^{* * *}$ Federal de Minas Gerais University; Institute of Exact Sciences; Department of Statistic; Belo Horizonte; Minas Gerais; Brazil.

Correspondence: fabiolabarroso@vet.dout.ufmg.br
} 


\section{Introduction}

Spontaneous sebaceous neoplasms appear as one of the most frequent neoplasms in dogs. This kind of neoplasm represents the third most common type of skin tumors, as it accounts for $22-35 \%$ of all cutaneous epithelial tumors (SCOTT, D.W. and ANDERSON, W.I., 1990; VAIL, D.M. and WITHROW, S.J., 2007; BRONDEN, L.B., et al. 2010). In addition to that, they can be classified according to their histological appearance into three types: adenoma, epithelioma, and carcinoma (GROSS, T.L., et al. 2005). In the literature, it is stablished that sebaceous adenoma is the most predominant type of tumor (NODTVEDT, A. et al., 2012) and, although, sebaceous epitheliomas and carcinomas are less frequently found, they may recur after surgical treatment or lead to distant metastases (BETTINI, G., et al. 2009; SABATTINI, S., et al. 2015; YOON, J.S. and PARK, J., 2016).

In tumors in which basaloid cells predominate, such as in carcinoma and sebaceous epithelioma, histopathological diagnosis can be difficult. It also can be confused with basal carcinomas and poorly differentiated squamous carcinomas (SABATTINI, S., et al. 2015). Therefore, both in humans and in dogs, this diagnosis may require complementary immunohistochemistry (SABATTINI, S., et al. 2015; YOON, J.S. and PARK, J., 2016).

The cell proliferation markers such as, anti-Ki-67 and anti-PCNA, are frequently used as complementary immunohistochemistry (BRODZKI, A., et al., 2014; SABATTINI, S., et al. 2015; ABDULKADIR, S. N., et al., 2016). The PCNA protein was first identified by Miyachi et al. (1978). PCNA increases after the G1 phase of the cell cycle, reaching a maximum at the $S$ phase and decreasing after G2; then, it presents low levels in the M phase and quiescent cells (TSUJI, T., et al. 1992). Moreover, the PCNA protein is well known for being a cell cycle marker and it was detected in normal proliferating cells, transformed cells, and also in tumors (BRAVO, R. and CELIS, J.E., 1980; CELIS, J.E. and CELIS, A., 1985). This protein is also related to nucleic acid metabolism, DNA replication (PRELICH, G. and STILLMAN, B., 1988; DOWNEY, K.M., 1990), DNA repair, RNA transcription (MAGA, G. and HUBSCHER, 2003), and cell cycle control (WAGA, S., et al. 1994).

Several studies such as Peña et al. (1998), Carvalho et al. (2016), and Mestrinho et al. (2017) used the tumor cell proliferation marker anti-PCNA in canine mammary neoplasms and oral canine squamous cell carcinomas. To the best of our knowledge, only Brodzki et al. (2014) used the anti-Ki-67 marker to report tumor ontogenetically similar to sebaceous ones like perianal tumor.

Based on this background information, the aim of our study was to investigate anti-PCNA immunoexpression in canine sebaceous tumors and its possible association with the malignancy of the tumors.

\section{Material and Methods}

We selected 59 samples of canine sebaceous tumors from paraffin blocks that were located on the archive of the Veterinary Anatomic Pathology Laboratory of Federal Fluminense University, in Niterói, RJ, Brazil. These samples were collected from 53 different animals (53 sebaceous tumors and 6 normal tissues). The reports related to these samples were recovered; they informed characteristics such as animal identification, macroscopic and microscopic description, and histopathological diagnosis. We made new sequential slides for histopathological and immunohistochemical evaluation. Our aim with this strategy was to enable the fields evaluated for the two mentioned techniques to be as similar as possible.

The paraffin blocks were cut to 4-5 $\mu \mathrm{m}$ thickness. These cuts were arranged on conventional glass slides (H\&E staining) or silanized glass slides (immunostaining). All these cases had already been classified according to World Health Organization (WHO) criteria for epithelial skin tumors of domestic animals (GOLDSCHMIDT, M.H., et al. 1998). These classifications were revisited, and no discordance was found. As complementary classification we used the ideas seen in Tavares et al. (2012) and Peña et al. (2013). Tavares et al. (2012) focused on sebaceous tumors in humans. They characterized with details the structure of the lesion using circumscription and growth pattern, histoarchitecture, epithelium ratio and ulceration. In turn, the proposition of Peña et al. (2013) consisted on mitosis quantification in $10 \mathrm{HPF}$ (high-power field) and nuclear pleomorphism intensity. These two methods were chosen due to (i) consider the similarity of sebaceous tumors between humans and dogs, and (ii) the ontological proximity of the glands - sebaceous and mammary.

The immunostaining was performed using the streptavidin-biotin peroxidase complex technique (LSAB ${ }^{\circledR}+$ System-HRP/Dako) as recommended by the manufacturer. Then, the antigenic recovery was executed by heat using water bath at $98^{\circ} \mathrm{C}$ for 30 minutes. After that, incubation with primary monoclonal anti-PCNA antibody (clone PC10; Dako; dilution: 1:500) was used at $4^{\circ} \mathrm{C}$. The labelling was processed overnight. At last, the immunoreactivity was visualized by incubation with diaminobenzidine (DAB) (Liquid DAB+substrate, chromogen System-Dako) for five minutes and counterstained with Harris hematoxylin. We used sections of canine tonsil as positive and negative control groups.

The evaluation of the results obtained with steps described above are followed by the interpretation of PCNA immunoreactivity. To do so, we used the quantitative method proposed in Peña et al. (1998). This method is performed using a light microscope and it shows positivity when the staining occurs in the cell nucleus, regardless of the intensity. It is necessary to observe ten randomly selected areas of the tumor with more intense and homogeneous nuclear positivity. Next, in each tumor, we count the positive and negative cell nucleus in $10 \mathrm{HPF}$, with a minimum of 1.000 neoplastic cells. The proportion of positive neoplastic cells in each sample was determined in percentage terms configuring a positive index $(\mathrm{PI})$.

We performed the process for only one tumor from each animal. In case there was multicentric presentation of sebaceous tumors, the most malignant neoplasm was considered (in this order: carcinoma > epithelioma > adenoma). In addition to that, we analyzed six normal tissues. The dogs from which these samples were collected are within the set of the other animals aforementioned. Three of them presented sebaceous hyperplasia, and three of them had sebaceous adenoma. Nonneoplastic and neoplastic sebaceous tumors were grouped according to their location: head, eyelid, trunk, limb and perianal region. Moreover, tumor size was grouped in T1 $(<3 \mathrm{~cm})$; T2 (3-5 
cm) or T3 (>5 cm) (PEÑA, L., et al. 2013) and skin ulceration evaluation was performed. This study was approved by the Ethics Committee for the Use of Animals (CEUA) at Federal Fluminense University under protocol number $791 / 2016$

We analyzed data descriptively as well as using non-parametric methods. The WilcoxonMann-Whitney test was used to compare the distribution of anti-PCNA labelling within the groups age and reproductive status. In the case where the variable presented more than two groups - size of tumor, location of tumor, and histopathological type - we applied the Analysis for Variance (ANOVA). We also analyzed the correlation between the antiPCNA labelling of the normal tissue group and sebaceous tumor in the same animals, using Pearson Correlation Test. Statistical results were considered significant when $p<0.05$. All statistical analyses were performed using Statistical software R, version 3.6.1.

\section{Results}

Analysis of the samples showed a total of $58.49 \%(31 / 53)$ sebaceous tumors diagnosed in female dogs and $41.51 \%(22 / 53)$ in male dogs. The age of the animals ranged from 5 to 15 years (mean of 10.49 years and the standard deviation of 2.64). The most frequent breeds were Caniches, representing $30.19 \%(16 / 53)$ of the animals, and Cocker Spaniels, with 9.43\% (5/53). Mixed breed dogs represented $16.98 \%$ (9/53). The most common histopathological type was sebaceous adenoma, composing $37.74 \%(20 / 53)$ of the cases followed by sebaceous hyperplasia, with $32.08 \%$ (17/53); then sebaceous carcinoma, were $16.98 \%$ (9/53) of the samples; at last, sebaceous epithelioma accounted for $13.21 \%(7 / 53)$ of the studied cases.

Histoarchitecture and growth patterns beyond the circumscription were listed in Table 1 and illustrated in Figure 1. Focusing on the circumscription, most neoplastic tumors had unrestricted margins, regardless of malignancy. In what concerns the growth pattern, the exo-endophytic presentation was more frequent. The predominant histoarchitecture was the multilobular layout and the largest proportion was of the sebaceous component over basaloid. Ulceration and necrosis were frequent findings in sebaceous carcinomas and in some epitheliomas. The nuclear pleomorphism was mostly moderate, however, two sebaceous carcinomas and one epithelioma had marked nuclear atypia. The number of mitosis observed in carcinomas was high, with $77.80 \%$ ( $7 / 9$ cases) presenting 17 or more mitoses in $10 \mathrm{HPF}$; in epitheliomas, they were more than half of these cases (4/7).

Inflammatory infiltration was a common finding in all neoplastic lesions, ranging from discrete to marked. Within adenomas,
Table 1: Canine. Frequency and percentage of histopathological characteristics of tumors of the sebaceous glands

\begin{tabular}{|c|c|c|c|}
\hline \multicolumn{4}{|c|}{ Variable } \\
\hline & Adenoma & Epithelioma & Carcinoma \\
\hline \multicolumn{4}{|l|}{ Circumscription } \\
\hline Yes & $35 \%(7 / 20)$ & $28.6 \%(2 / 7)$ & $0.0 \%(0 / 9)$ \\
\hline No & $65 \%(13 / 20)$ & $71.4 \%(5 / 7)$ & $100.0 \%(9 / 9)$ \\
\hline \multicolumn{4}{|l|}{ Growth pattern } \\
\hline Exophytic & $10 \%(2 / 20)$ & $0.0 \%(0 / 7)$ & $11.1 \%(1 / 9)$ \\
\hline Endophytic & $45 \%(9 / 20)$ & $28.6 \%(2 / 7)$ & $22.2 \%(2 / 9)$ \\
\hline Exo-endophytic & $45 \%(9 / 20)$ & $71.4 \%(5 / 7)$ & $66.7 \%(6 / 9)$ \\
\hline \multicolumn{4}{|l|}{ Histoarchitecture } \\
\hline Multilobular & $75 \%(15 / 20)$ & $71.4 \%(5 / 7)$ & $77.8 \%(7 / 9)$ \\
\hline Cystic & $15 \%(3 / 20)$ & $0.0 \%(0 / 7)$ & $22.2 \%(2 / 9)$ \\
\hline Keratoacanthoma-like & $10 \%(2 / 20)$ & $28.6 \%(2 / 7)$ & $0.0 \%(0 / 9)$ \\
\hline \multicolumn{4}{|c|}{ Epithelium ratio (sebaceous/basal) } \\
\hline $3 / 1$ & $80 \%(16 / 20)$ & $0.0 \%(0 / 7)$ & $0.0 \%(0 / 9)$ \\
\hline $2 / 2$ & $20 \%(5 / 20)$ & $0.0 \%(0 / 7)$ & $33.3 \%(3 / 9)$ \\
\hline $1 / 3$ & $0.0 \%(0 / 20)$ & $100.0 \%(7 / 7)$ & $66.7 \%(6 / 9)$ \\
\hline \multicolumn{4}{|l|}{ Ulceration } \\
\hline Present & $35 \%(7 / 20)$ & $57.1(4 / 7)$ & $100.0 \%(9 / 9)$ \\
\hline Absent & $65 \%(13 / 20)$ & $42.9(3 / 7)$ & $0.0 \%(0 / 9)$ \\
\hline \multicolumn{4}{|l|}{ Nuclear Pleomorphism } \\
\hline Discrete & $75 \%(15 / 20)$ & $0.0 \%(0 / 7)$ & $0.0 \%(0 / 9)$ \\
\hline Moderate & $25 \%(5 / 20)$ & $85.7 \%(6 / 7)$ & $77.8 \%(7 / 9)$ \\
\hline Marked & $0.0 \%(0 / 20)$ & $14.3 \%(1 / 7)$ & $22.2 \%(2 / 9)$ \\
\hline \multicolumn{4}{|c|}{ Mitosis (10 high-power field) } \\
\hline $0-8$ & $60 \%(12 / 20)$ & $14.3 \%(1 / 7)$ & $0.0 \%(0 / 9)$ \\
\hline $9-16$ & $40 \%(8 / 20)$ & $28.6 \%(2 / 7)$ & $22.2 \%(2 / 9)$ \\
\hline$\geq 17$ & $0.0 \%(0 / 20)$ & $57.1 \%(4 / 7)$ & $77.8 \%(7 / 9)$ \\
\hline \multicolumn{4}{|l|}{ Necrosis } \\
\hline Present & $0.0 \%(0 / 20)$ & $42.9 \%(3 / 7)$ & $77.8 \%(7 / 9)$ \\
\hline Absent & $100.0 \%(20 / 20)$ & $57.1 \%(4 / 7)$ & $22.2 \%(2 / 9)$ \\
\hline
\end{tabular}

this infiltration was composed by moderate number of lymphocytes, plasma cells and neutrophils. On the other hand, sebaceous epitheliomas had accentuated inflammatory infiltrate characterized by lymphocytes, plasmocytes, neutrophils and histiocytes. As the last group of tumors, sebaceous carcinomas exhibited moderate to marked inflammatory infiltration characterized by lymphocytes, plasma cells, neutrophils, and histiocytes (see Figure 1).

Out of the nine sebaceous carcinomas evaluated, two of them had both lymphatic oncotic invasion and compromised surgical margins. On the other hand, only one sebaceous epithelioma had compromised surgical margin.

The immunoreactivity for PCNA was observed in the nucleus. Figure 2 shows variation of the positivity index considering the 


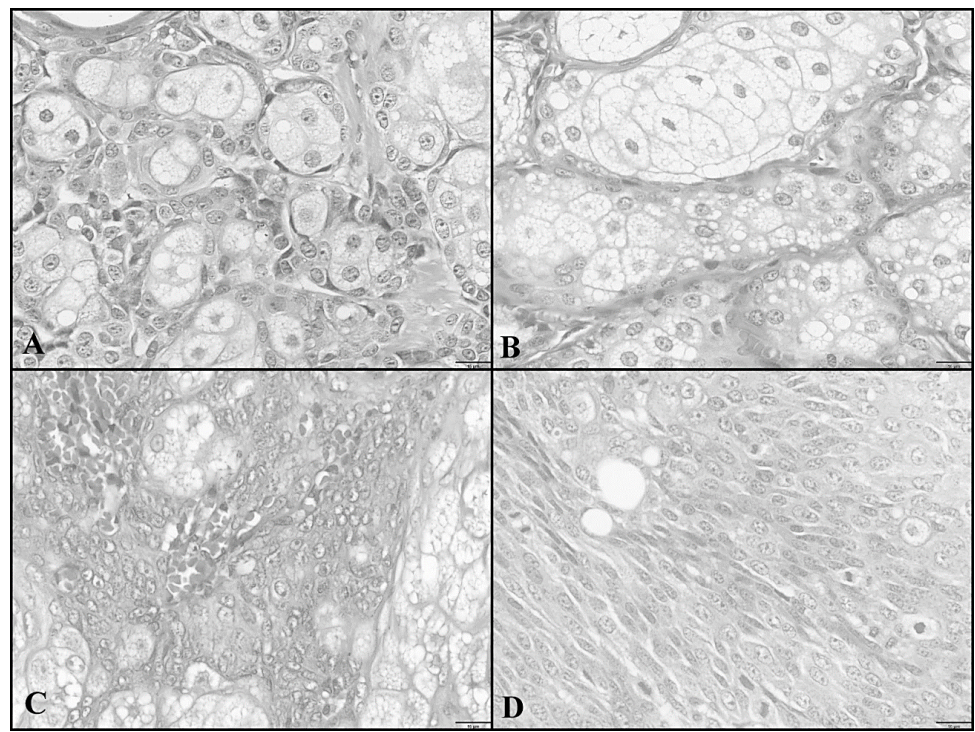

Figure 1: Canine. Sebaceous gland tumors. A. Sebaceous adenoma. Basaloid cell population proportionally higher (black arrowhead). B. Sebaceous hyperplasia. Note numerous sebaceous lobes histologically normal. C. Sebaceous epithelioma. Predominance of basaloid cells (black arrowhead), and associated, there is lymphoplasmacytic inflammation and diffuse congestion moderate (hollow arrowhead). D. Sebaceous carcinoma. Numerous typical (black arrowhead) and atypical mitoses (hollow arrowhead). Hematoxylin and Eosin (H\&E) staining, high magnification (400x), bar: $16 \mu \mathrm{m}$.

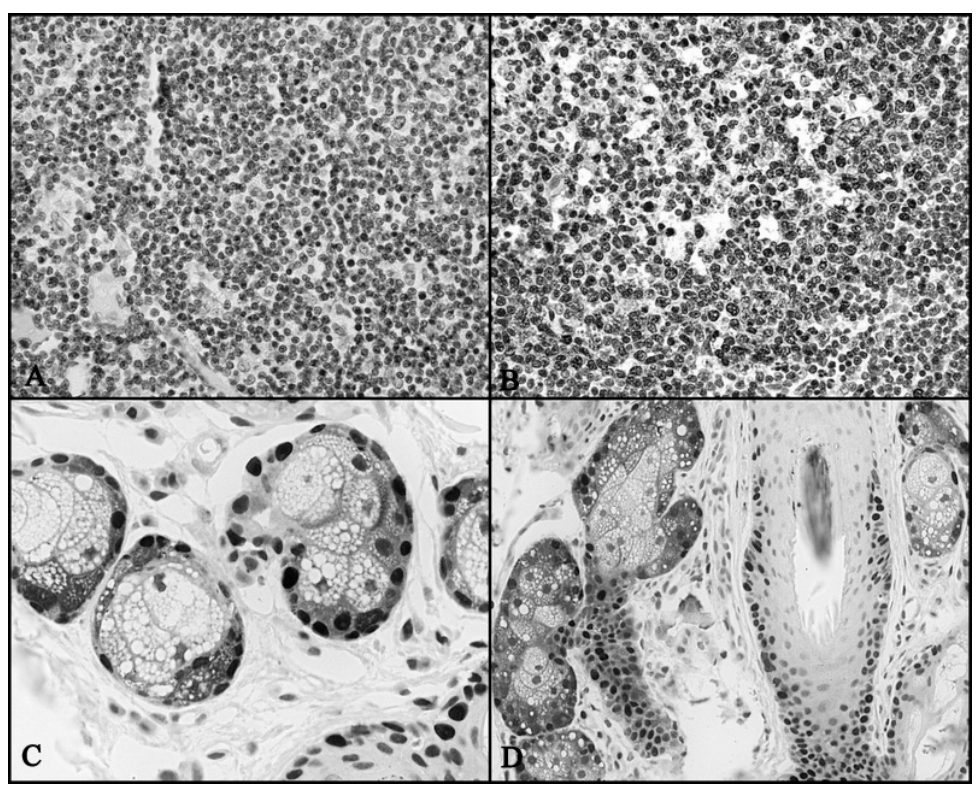

Figure 2: Canine. Tonsil and Normal Sebaceous glands. A. Canine tonsil. Negative control of labelling of anti-PCNA. B. Canine tonsil. Positive control of labelling of antiPCNA. C and D. Normal Sebaceous gland. Predominance of labelling in basaloid cells (black arrowhead). Anti-PCNA immunostaining, high magnification (400x).

negative and positive controls, as well as the normal tissues. In this figure, Panel (a) illustrates negative control of the reaction (canine tonsil); Panel (c) refers to the positive control (canine tonsil); and Panels (c, d) shows the PCNA labelling in normal sebaceous glands. PCNA's positive cells were found both in the tumors and normal tissues. Regarding normal tissues, PI ranged from $3.73 \%$ to $9.98 \%$; in the group of sebaceous hyperplasia, $\mathrm{PI}$ varied from $4.66 \%$ to $51.49 \%$. Among neoplastic lesions, the PI varied from $3.34 \%$ to $57.62 \%$ in adenomas, $5.70 \%$ to $48.82 \%$ in epitheliomas, and $5.54 \%$ to $60.70 \%$ in carcinomas. As a comparison, Figure 3 shows an elevated marked reaction in sebaceous carcinoma.

Figure 4 shows the boxplots comparing the anti-PCNA labelling between the histopathological types, they were hyperplasia, adenoma, epithelioma, carcinoma, and normal tissue. We separated this figure into two panels in what concerns the 
outliers. Thus, Panel (a) does not represent these values, in opposition to Panel (b). With this figure, we can observe that the anti-PCNA seems to be similar within these groups. In turn, in Table 2 we can evaluate the frequencies of the gender in groups of the variables, such as the age, reproductive status, size and location of tumor and histopathological types. In Table 2, we also can observe the mean of anti-PCNA labelling in each of the mentioned groups as well and the p-value of the WilcoxonMann-Whitney test and ANOVA test.

According to the results, no significant difference was observed between anti-PCNA labelling and the groups of all variable analyzed. It means that anti-PCNA labelling can be considered similar between younger and older dogs ( $p$-value $=0.1267$ ), castrated and not castrated ( $p$-value $=0.7575$ ). Regarding the characteristics of the tumor, it is also similar between the sizes T1, T2 and T3 (p-value $=0.7100$ ) as well as the location, which could be head, limb, eyelid, perianal, or trunk ( $p$-value $=0.9950)$. At last, there was not difference of the anti-PCNA between the different histopathological types of sebaceous tumors $(p$-value $=$ $0.6470)$. We mention that we did not included the values of antiPCNA labelling regarding the normal tissue group in this latter analysis. This decision was based on the fact that the animals from which these samples were colleted were already considered in some of the other histopathological types. These valued can be seen in Table 3. We also analyzed the correlation between the anti-PCNA labelling of the mentioned samples; it showed to be uncorrelated $(\rho=-0.0205$, $p$-value $=0.9692)$.

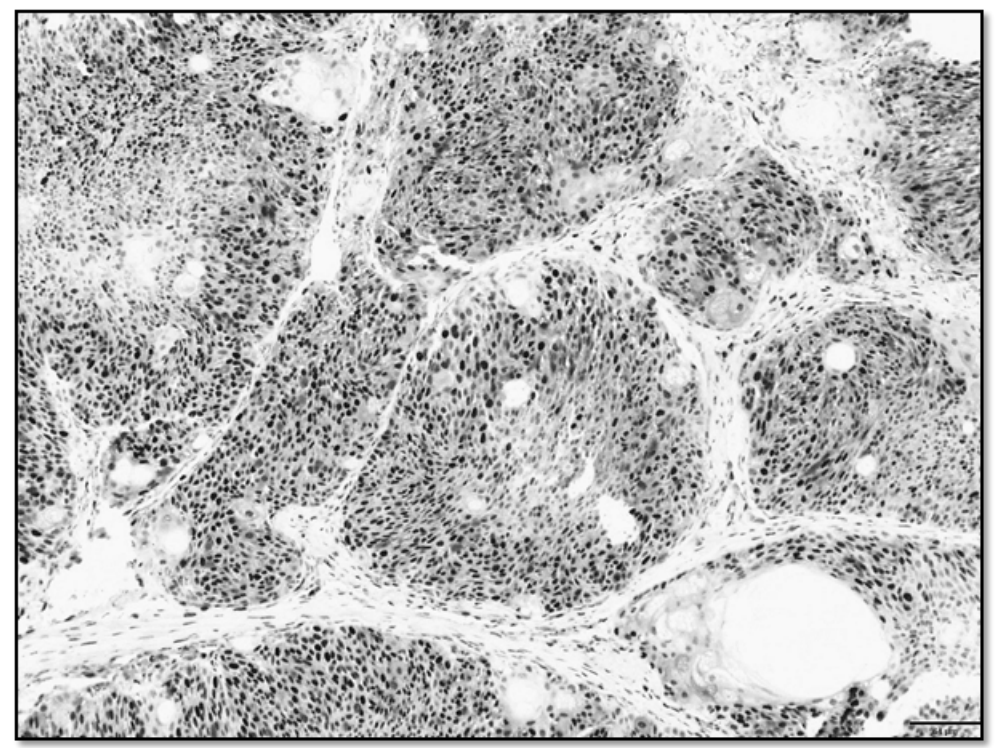

Figure 3: Canine. Sebaceous Carcinoma. Immunohistochemistry with anti-PCNA antibody. Note PCNA positive nucleus cells, characterizing high rate of proliferation. Anti-PCNA immunostaining, low magnification (200x), bar: $64 \mu \mathrm{m}$.

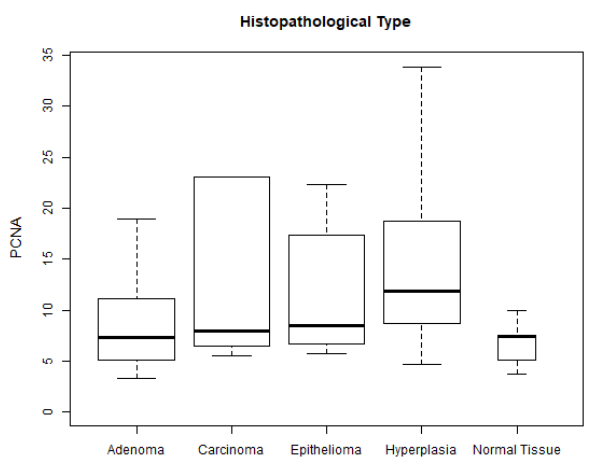

A

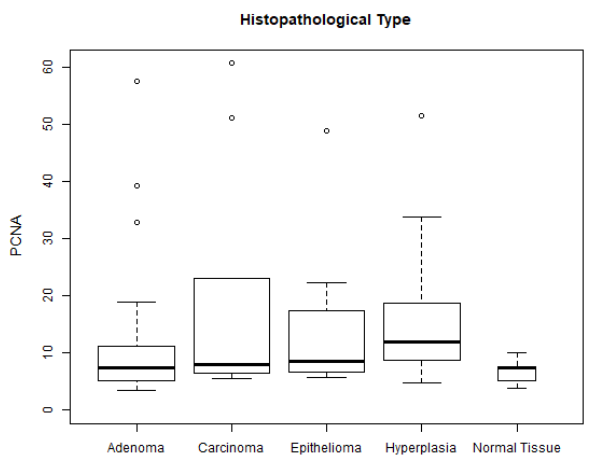

B

Figure 4: Boxplot demonstrating the distribution of the positivity index (PI) for the anti-PCNA labelling antibody for normal sebaceous tissues as well as for the different types of canine sebaceous tumors found in this study. Panel (a) shows no outliers and Panel (b) illustrates all values. Comparison between the mean values of anti-PCNA of the groups of sebaceous tumors showed no difference according to the ANOVA test ( $p$-value $=0.6470$ ) (since the animals in the group of the normal tissue were within the set of the other categories of sebaceous tumors, we did not compare the values of anti-PCNA in the ANOVA test). 
Table 2: Canine sebaceous tumors. Frequency of the gender of the animals in the groups of the evaluated variables, as all as the results of the WilcoxonMann-Whitney test ${ }^{+}$and ANOVA test ${ }^{++}$

\begin{tabular}{|c|c|c|c|c|}
\hline Variable & Gender & $N$ & $\begin{array}{c}\text { PCNA labelling } \\
\text { index }(\%)\end{array}$ & $P$ \\
\hline \multicolumn{5}{|l|}{ Age groups } \\
\hline$<10$ years & $\begin{array}{l}9 \stackrel{9}{+} \\
9 \hat{O}\end{array}$ & 18 & 12.42 & $0.1267^{+}$ \\
\hline$\geq 10$ years & $\begin{array}{l}22+ \\
13 \hat{0} \\
\end{array}$ & 35 & 22.13 & \\
\hline \multicolumn{5}{|l|}{ Reproductive status } \\
\hline Castrated & $\begin{array}{l}22 \text { 早 } \\
5 \hat{0}\end{array}$ & 27 & 14.76 & $0.7575^{+}$ \\
\hline Not castrated & 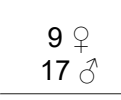 & 26 & 16.72 & \\
\hline \multicolumn{5}{|l|}{ Size } \\
\hline $\mathrm{T} 1(<3 \mathrm{~cm})$ & $\begin{array}{l}12 \text { ㅇ } \\
7 \stackrel{0}{\lambda}\end{array}$ & $\begin{array}{l}19 \\
.\end{array}$ & 16.04 & \\
\hline T2 $(3-5 \mathrm{~cm})$ & $\begin{array}{l}10+ \\
6 \stackrel{+}{1}\end{array}$ & 16 & 17.80 & $0.7100^{++}$ \\
\hline $\mathrm{T} 3(>5 \mathrm{~cm})$ & $\begin{array}{l}9 \text { o } \\
90 \\
\end{array}$ & 18 & 13.54 & \\
\hline \multicolumn{5}{|l|}{ Location } \\
\hline Head & 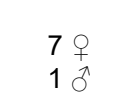 & 8 & 16.12 & \\
\hline Limb & $\begin{array}{l}3 \text { 古 } \\
2 \stackrel{\pi}{0}\end{array}$ & 5 & 13.63 & \\
\hline Eyelid & $\begin{array}{l}7 \stackrel{9}{7} \\
6 \stackrel{\lambda}{0}\end{array}$ & 13 & 16.33 & $0.9950^{++}$ \\
\hline Perianal & $\begin{array}{l}5 \text { q } \\
9 \hat{O}\end{array}$ & 14 & 16.56 & \\
\hline Trunk & $\begin{array}{l}9 \stackrel{9}{9} \\
4 \hat{0}\end{array}$ & 13 & 14.77 & \\
\hline \multicolumn{5}{|l|}{ Histopathological type } \\
\hline Sebaceous Hyperplasia & $\begin{array}{l}11 \text { ㅇ } \\
6 \stackrel{1}{0}\end{array}$ & 17 & 16.28 & \\
\hline Sebaceous Adenoma & $\begin{array}{l}12+ \\
8{ }^{\lambda}\end{array}$ & 20 & 12.96 & \\
\hline Sebaceous Epithelioma & $\begin{array}{l}5 \stackrel{+}{+} \\
2 \hat{O}\end{array}$ & 7 & 15.84 & $0.6470^{++}$ \\
\hline Sebaceous Carcinoma & $\begin{array}{l}3 \stackrel{+}{+} \\
6 \stackrel{\lambda}{0}\end{array}$ & 9 & 20.70 & \\
\hline Normal Sebaceous Tissue* & $\begin{array}{l}3 \stackrel{9}{+} \\
3 \hat{\jmath}\end{array}$ & 6 & 6.85 & \\
\hline
\end{tabular}

+Wilcoxon Test; ${ }^{++}$ANOVA Test; ${ }^{*}$ this group was not included in the ANOVA test

o female; ${ }^{1}$ male; ++N: absolute number; $\mathrm{P}$ : $\mathrm{p}$-value 
Table 3: Canine sebaceous tumors. Comparison of PCNA labelling index (\%) for both sebaceous tumors and normal tissues of the same animals

\begin{tabular}{cccc}
\hline \multirow{2}{*}{ ID } & Histhopathological & \multicolumn{2}{c}{ PCNA labelling index (\%) } \\
\cline { 3 - 4 } & Diagnostic & $\begin{array}{c}\text { Sebaceous } \\
\text { Tumor }\end{array}$ & $\begin{array}{c}\text { Normal } \\
\text { Tissue }\end{array}$ \\
\hline $231 / 13-8$ & Sebaceous Hyperplasia & 18.76 & 7.41 \\
$12 / 14-1$ & Sebaceous Hyperplasia & 11.85 & 7.55 \\
$43 / 14-7$ & Sebaceous Hyperplasia & 11.98 & 5.09 \\
$117 / 13-8$ & Sebaceous Adenoma & 5.33 & 9.98 \\
$64 / 14-1$ & Sebaceous Adenoma & 6.06 & 3.73 \\
$80 / 15-4$ & Sebaceous Adenoma & 6.72 & 7.32 \\
\hline
\end{tabular}

Pearson Correlation Test $(\rho=-0.0205, p$-value $=0.9692)$.

\section{Discussion}

Sebaceous tumors are common in dogs and are among the most common lesions in older animals, as highlighted by Dobson et al. (2002), Merlo et al. (2008) and Vascellari et al. (2009). According to Pakhrin et al. (2007), $27.7 \%$ of localized skin tumors and appendages had its origins in sebaceous tumors. The results the mentioned study showed that, of the ten most lesions diagnosed, $6.68 \%$ were sebaceous adenoma, $5.08 \%$ sebaceous hyperplasia, and $3.61 \%$ were perianal adenomas. Our findings revealed that $32.08 \%(17 / 53)$ of the lesions were hyperplastic, and $67.92 \%$ (36/53) were neoplastic. Considering the neoplastic tumors, $75.00 \%(27 / 36)$ were benignant - which included both sebaceous adenoma and sebaceous epithelioma. Our results were similar to the findings of previous studies Macvean, et al. (1978), Dobson, et al. (2002), Pakhrin, et al. (2007), Merlo, et al. (2008), Vascellari, et al. (2009), and Chikweto, et al. (2011).

Previous studied point out to the breeds of Caniche and Cocker Spaniel as the most predisposed to the development of sebaceous tumors (SCOTT, D.W. and ANDERSON, W.I., 1990; MERLO, D.F., et. al. 2008; BRONDEN, L.B., et al. 2010; TAVARES E., et al. 2012). We also have encountered such result. Moreover, Adams, et al. (2010), found that $29.7 \%$ of the causes of death in Caniche are related to cancer. In the breed of Cocker Spaniel, it represents $29.4 \%$ of the causes of death. According to same authors, the average of the life expectancy was 12 years for Caniche and 11.17 years for Cocker Spaniel. This causes of death and life expectancy can be a theme of future study.

Although most of canine sebaceous tumors have a good prognosis, benign tumors may occur in multicentric sites requiring frequent surgeries. Furthermore, the predominantly exo-endophytic growth pattern predisposes to ulceration and inflammation. It can also lead to functional problems in the location of growth (SCOTT, D.W. and ANDERSON, W.I., 1990; GROSS, T.L., et al. 2005; BETTINI, G., et al. 2009; SABATTINI, S., et al. 2015).

The histopathological findings observed in the sebaceous tumors of the evaluated population were diverse. The sebaceous carcinomas invaded adjacent tissues, leading to ulceration. In two cases there was oncotic embolism in lymphatic vessels; the same was observed by Sabattini, et al. (2015). In addition, nuclear pleomorphism ranged from moderate to severe and tumor necrosis were common findings. Necrosis were also present in $42.9 \%$ of sebaceous epitheliomas. Moreover, mitosis was proportionally higher in benign neoplasms.

The classification of tumors with an abundant basaloid component can be a challenge. There are definitions of new histopathological entities, but they are not yet a consensus among researchers. For example, the category of "epitheliomatous carcinoma" was suggested by Gross, et al. (2005) to characterize a malignant sebaceous tumor better differentiated than the sebaceous carcinoma. The proposed category was based on the proportion of the basaloid component. With this matter in mind, additional diagnostic tools have been used to improve the characterization and distinction of these tumors. Among them we can cite, immunohistochemistry, which is commonly used in human pathology (ANSAI, S., et al. 1994; CABRAL, E.S., et al. 2006; ANSAI, S., et al. 2011). However, in dogs, few studies have described the immunohistochemical characterization of sebaceous tumors. Most of these studies included different cytokeratins (KATO, K., et al. 2007; YASUNO, K., et al. 2009; YOON, J.S. and PARK, J., 2016), p63 expression (SARAIVA, A.L., et al. 2008), survivin (BONGIOVANNI, L., et al. 2012), and Ki-67 cell proliferation marker (MIYACHI, K., et al. 1978; BRODZKI, A., et al. 2014; SABATTINI, S., et al. 2015; YOON, J.S. and PARK, J., 2016). In addition to that, to the best of our knowledge, PCNA expression in canine sebaceous tumors had not been investigated yet.

A variety of tumors are labeled for PCNA, both in humans (KUANG, R.G., et al. 2013; POOSARLA, C., et al. 2015; ABDULKADIR, S.N., et al. 2016) and in dogs (PEÑA, L.L., et al. 1998; CARVALHO, M.I., et al. 2016; MESTRINHO, L.A., et al. 2017). Mestrinho, et al. (2017) using survival analysis, found out that PCNA labelling index $\geq 65 \%$ for canine oral squamous cell carcinoma (OSCC) resulted in lower disease-free survival. In our study, PCNA labelling index ranged from $3.34 \%$ to $57.62 \%$ for adenoma, $5.70 \%$ to $48.82 \%$ for epithelioma and $5.54 \%$ to $60.70 \%$ for carcinoma. In an overall comparison, other studies found PCNA labelling index values greater than ours: Carvalho, et al. (2016) evaluated canine mammary tumors and Mestrinho, et al. (2017) focused on OSCC. The difference in these findings may reflect the idea that a low PCNA index level - which we dealt with - might reflect non-metastasis and relatively good prognoses for the cases.

Carvalho et al. (2016), treating canine mammary neoplasms, found PCNA immunoreactivity in benign tumors varying around $20-49 \%$, and $12 \%-47 \%$ in adjacent non-neoplastic tissues. For the malignant tumors, immunostaining ranged from $21 \%-69 \%$, and $10 \%-40 \%$ in adjacent non-neoplastic tissues. These results indicate a wide range of immunoreactivity, which were associated with clinicopathological characteristics of tumor aggressiveness.

In our study there was no statistical association between the different histological types and the various factors related to canine sebaceous tumors. Anti-PCNA labelling was detected in all tumor types at varying levels, and in normal sebaceous glands with low positivity index. In order to infer about the role of anti-PCNA as a predictor of malignancy in sebaceous tumors of dogs in a more accurate manner, it is necessary to expand the evaluation of samples in normal and tumoral glands, preferably within a similar population in terms of sex, age, breed and reproductive status. 


\section{Conclusion}

In the present study, we analyzed the distribution of anti-PCNA labelling and possible associated variables. However, we did not find any statistical difference of the anti-PCNA labelling between the groups the histopathological diagnosis of sebaceous tumors in dogs and other variables such as sex, age, breed, reproductive status, location, and size of the tumors.

\section{Declaration of Conflicting Interests}

The author(s) declared no potential conflicts of interest with respect the research, authorship, and/or publication of this article.

\section{Funding}

This work was financially supported by Conselho Nacional de Desenvolvimento Científico e Tecnológico (CNPq) and Coordenação de Aperfeiçoamento de Pessoal de Nível Superior (CAPES), Brazil.

\section{Acknowledgements}

The authors thank all of the dog owners who authorized the use of the data and samples of their animals.

\section{References}

ABDULKADIR, S.N.; ALI, N.R.; ALCHALABI, N.J. Pathological Study of Oral Squamous Cell Carcinoma by Application of P53 and PCNA (Immunohistochemical Approach). International Journal of Current Microbiology and Applied Sciences. v.5, n.4, p.91-100, 2016.

ADAMS, V.J.; EVANS, K.M.; SAMPSON, J.; WOOD, J.L.N. Methods and Mortality Results of a Health Survey of Purebred Dogs in the UK. The Journal of Small Animal Practice. v.51, n.10, p.512-24, 2010.

ANSAI, S.; ARASE, S.; KAWANA, S.; KIMURA, T. Immunohistochemical findings of sebaceous carcinoma and sebaceoma: retrieval of cytokeratin expression by a panel of anti-cytokeratin monoclonal antibodies. J. Dermatol. v.38, n.10, p.951-58, 2011.

ANSAI, S.; KATAGATA, Y.; YOSHIKAWA, K.; HASHIMOTO; H.; HOZUMI, Y.; KONDO, S.; ASO, K. An immunohistochemical study of sebaceous carcinoma with antikeratin monoclonal antibodies: comparison with other skin cancers. J. Dermatol. v.21, n.8, p.55359, 1994.

BETTINI, G.; MORINI, M.; MANDRIOLI, L.; CAPITANI, O.; GANDINI, G. Central nervous system and lung metastasis of sebaceous epithelioma in a dog. Veterinary Dermatology. v.20, n.4, p.289-94, 2009.

BONGIOVANNI, L.; SUTER, M.M.; MALATESTA, D.; ORDINELLI, A.; CICCARELLI, A.; ROMANUCCI, M.; BRENNER, O.; DELLA SALDA, L. Nuclear survivin expression as a potentially useful tool for the diagnosis of canine cutaneous sebaceous lesions. Vet. Dermatol. v.23, n.5, p.394-99, 2012.

BRAVO, R. and CELIS, J.E. A search for differential polypeptide synthesis throughout the cell cycle of HeLa cells. J. Cell Biol. v.84, n.3, p.795-802, 1980.

BRODZKI, A.; ŁOPUSZYŃSKI, W.; BRODZKI, P.; TATARA, M.R. Diagnostic and prognostic value of cellular proliferation assessment with $\mathrm{Ki}-67$ protein in dogs suffering from benign and malignant perianal tumors. Folia Biol (Krakow). v.62, n.3, p. 235-41, 2014.
BRONDEN, L.B.; NIELSEN, S.S.; TOFT, N.; KRISTENSEN, A.T. Data from the Danish Veterinary Cancer Registry on the Occurrence and Distribution of Neoplasms in Dogs in Denmark. The Veterinary Record. v.19, n.166, p.586-90; 2010.

CABRAL, E.S.; AUERBACH, A.; KILLIAN, J.K.; BARRETT, T.L.; CASSARINO, D.S. Distinction of benign sebaceous proliferations from sebaceous carcinomas by immunohistochemistry. Am. J. Dermatopathol. v.28, n.6, p. 465-71, 2006.

CARVALHO, M.I.; PIRES, I.; PRADA, J.; LOBO, L.; QUEIROGA, F.L. Ki67 and PCNA Expression in Canine Mammary Tumors and Adjacent Nonneoplastic Mammary Glands: Prognostic Impact by a Multivariate Survival Analysis. Vet Pathol. v.53, n.6, p.1138-46, 2016.

CELIS, J.E. and CELIS, A. Cell cycle-dependent variations in the distribution of the nuclear protein cyclin proliferating cell nuclear antigen in cultured cells: subdivision of S phase. Proc. Natl. Acad. Sci. U.S.A. v.82, n.10, p.3262-66, 1985.

CHIKWETO, A.; MCNEIL, P.; BHAIYAT, M.I.; STONE, D.; SHARMA, R.N. Neoplastic and Nonneoplastic Cutaneous Tumors of Dogs in Grenada, West Indies. ISRN Veterinary Science. v.2011, p.1-6, 2011.

DOBSON, J.M.; SAMUEL, S.; MILSTEIN, H.; ROGERS, K.; WOOD, J.L.N. Canine Neoplasia in the UK: Estimates of Incidence Rates from a Population of Insured Dogs. The Journal of Small Animal Practice. v.43, n.6, p. 240-46, 2002.

DOWNEY, K.M.; TAN, C.K.; SO, A.G. DNA polymerase delta: a second eukaryotic DNA replicase. Bioessays.v.12, n.1, p.231-36, 1990.

GOLDSCHMIDT, M.H., DUNSTAN, R.W.; STANNARD, A.A.; TSCHARNER, C.V.; WALDER, E.J.; YAGER, J.A. Histological classification of epithelial and melanocytic tumors of the skin of domestic animals, Vol.III. World Health Organization International Classification of Tumors in Domestic Animals: Second Series. Armed Force Institute of Pathology; Washington, DC, USA. AFIP Letter, v.156, n.6, p.11-101, 1998.

GROSS, T.L.; IHRKE, P.J.; WALDER, E.J.; AFFOLTER, V.K. Sebaceous tumors. In: Skin Diseases of the Dog and Cat: Clinical and Histopathologic Diagnosis, 2th edn., Blackwell Publishing Company Ed., Oxford (United Kingdom), 2005, p.641-654. 
KATO, K.; UCHIDA, K.; NIBE, K.; TATEYAMA, S. Immunohistochemical studies on cytokeratin 8 and 18 expressions in canine cutaneous adnexus and their tumors. $J$. Vet. Med. Sci. v.69, n.3, p.233-39, 2007.

KUANG, R.G.; WU, H.X.; HAO, G.X.; WANG, J.W.; ZHOU, C.J. Expression and significance of IGF-2, PCNA, MMP-7, and $\alpha$-actin in gastric carcinoma with Lauren classification. The Turkish Journal of Gastroenterology. v.24, n.2, p.99-108, 2013.

MACVEAN, D.W.; MONLUX, A.W.; ANDERSON, P.S.; SILBERG, S.L.; ROSZEL, J.F. Frequency of Canine and Feline Tumors in a Defined Population. Veterinary Pathology. v.15, n.6, p.700-715, 1978.

MAGA, G. and HUBSCHER, U. Proliferation cell nuclear antigen (PCNA): a dancer with many partners. J. Cell Sci. v.116, n.15, p.3051-3060, 2003.

MERLO, D.F.; ROSSI, L., PELLEGRINO, C.; CEPPI, M.; CARDELLINO, U.; CAPURRO, C.; RATTO, A.; SAMBUCCO, P.L.; SESTITO, V.; TANARA, G.; BOCCHINI, V. Cancer Incidence in Pet Dogs: Findings of the Animal Tumor Registry of Genoa, Italy. Journal of Veterinary Internal Medicine. v.22, n.4, p.976-84, 2008.

MESTRINHO, L.A.; FAÍSCA, P.; PELETEIRO, M.C.; NIZA, M.M. PCNA and grade in 13 canine oral squamous cell carcinomas: association with prognosis. Vet Comp Oncol. v.15, n.1, p. 18-24, 2017.

MIYACHI, K.; FRITZLER, M.J.; TAN, E.M. Autoantibody to a nuclear antigen in proliferating cells. J. Immunol. v.121, n.6, p.2228-34, 1978.

NODTVEDT, A.; BERKE, O.; BONNETT, B.; BRODEN, L. Current Status of Canine Cancer Registration - Report from an International Workshop. Veterinary and Comparative Oncology. v. 10, n.2, p.95-101, 2012.

PAKHRIN, B.; KANG, M.S.; BAE, I.H.; PARK, M.S.; JEE, H.; YOU, M.H.; KIM, J.H.; YOON, B.I.; CHOI, Y.K.; KIM, D.Y. Retrospective Study of Canine Cutaneous Tumors in Korea. Journal of Veterinary Science. v.8, n.3, p.229-36, 2007.

PEÑA, L.; DE ANDRÉS, P.J.; CLEMENTE, M.; CUESTA, P.; PÉREZ-ALENZA, M.D. Prognostic value of histological grading in noninflammatory canine mammary carcinomas in a prospective study with two-year follow-up: relationship with clinical and histological characteristics. Vet Pathol. v.51, n.1, p.94-105, 2013.

PEÑA, L.L.; NIETO, A.I.; PÉREZ-ALENZA, D.; CUESTA, P.; CASTAÑO, M. Immunohistochemical detection of Ki-67 and PCNA in canine mammary tumors: relationship to clinical and pathologic variables. J Vet Diagn Investig Off Publ Am Assoc Vet Lab Diagn Inc. v.10, n.3, p.237-46, 1998.
POOSARLA, C.; RAMESH, M.; RAMESH, K.; GUDISEVA, S.; BALA, S.; SUNDAR, M. Proliferating Cell Nuclear Antigen in Premalignancy and Oral Squamous Cell Carcinoma. Journal of Clinical and Diagnostic Research : JCDR. v.9, n.6, p.ZC39-41, 2015.

PRELICH, G. and STILLMAN, B. Coordinated leading and lagging strand synthesis during SV40 DNA replication in vitro requires PCNA. Cell. v.53, n.1, p.117-126, 1988.

SABATTINI, S.; BASSI, P.; BETTINI, G. Histopathological Findings and Proliferative Activity of Canine Sebaceous Gland Tumours with a Predominant Reserve Cell Population. Journal of Comparative Pathology. v. 152, n. 2-3, p. 145-52, 2015.

SARAIVA, A.L.; GARTNER, F.; PIRES, M.A. Expression of p63 normal canine skin and primary cutaneous glandular carcinomas. Vet. J. v.177, n.1, p. 136-40, 2008.

SCOTT, D.W. and ANDERSON, W.I. Canine sebaceous gland tumors: a retrospective analysis of 172 cases. Canine Practice. v.15, n.1, p.19-27, 1990.

TAVARES E.; ALVES. R.; VIANA, I.; VALE, E. Tumores sebáceosrevisão anátomo-clínica de três tipos histológicos. Med Cutan Iber Lat Am. v.40, n.3, p.76-85, 2012.

TSUJI, T.; SHRESTHA, P.; YAMADA, K.; TAKAGI, H.; SHINOZAKI, F.; SASAKI, K.; MAEDA, K.; MORI, M.

Proliferating cell nuclear antigen in malignant and pre-malignant lesions of epithelial origin in the oral cavity and the skin: an immunohistochemical study. Virchows Arch A Pathol Anat Histopathol. v.420, n.5, p.377-83, 1992.

VAIL, D.M. and WITHROW, S.J. Tumors of the skin and subcutaneous tissues. In: Withrow and MacEwen's Small Animal Clinical Oncology, $4^{\text {th }}$ edn., SJ Withrow, DM Vail, Ed., Elsevier Saunders, St Louis, 2007, p.375-401.

VASCELLARI, M.; BAIONI, E.; RU, G.; CARMINATO, A.; MUTINELLI, F. Animal Tumour Registry of Two Provinces in Northern Italy: Incidence of Spontaneous Tumours in Dogs and Cats. BMC veterinary research. v.5, n.1, p.39, 2009.

WAGA, S.; HANNON, G.J.; BEACH, D.; STILLMAN, B. The p21 inhibitor of cyclin-dependent kinases controls DNA replication by interaction with PCNA. Nature. v.369, p. 574-78, 1994.

YASUNO, K.; NISHIYAMA, S.; SUETSUGU, F.; OGIHARA, K.; MADARAME, H.; SHIROTA, K. Cutaneous clear cell adnexal carcinoma in a dog: special reference to cytokeratin expression. $J$. Vet. Med. Sci. v.71, n.11, p. 1513-17, 2009.

YOON, J.S. and PARK, J. Immunohistochemical characterization of sebaceous epithelioma in two dogs. Iranian Journal of Veterinary Research. v.17, n.2, p.134-36, 2016. 